\title{
DUSTFALL MEASUREMENTS IN PRIMORSKO-GORANSKA COUNTY, 1975-2008
}

\author{
Vladimir MIĆOVIĆ, Ana ALEBIĆ-JURETIĆ, Nada MATKOVIĆ, and Goran CRVELIN \\ Teaching Institute of Public Health, Rijeka, Croatia
}

Received in March 2009

Accepted in October 2009

\begin{abstract}
Dustfall measurements in Primorsko-goranska county started in 1975 in the Bakar Bay (Site 2 - Bakar and Site 3 - Kraljevica). The measurements were extended to the city of Rijeka (Site 1 - Rijeka) in 1982, to the nearby islands (Site 4 - Krk and Site 5 - Cres) in 1986, and inland to Gorski Kotar (Site 6 - Delnice and Site 7 - Lividraga) in 1995. This article brings the results of dustfall measurements from 1975 to 2008. Dustfall was low in the city, the nearby islands, and Gorski Kotar. Recommended and limit values were occasionally exceeded in the Bakar Bay due to emissions from the coke plant and harbour at Site 2 (1979-1997) and from the shipyard at Site 3. Lead content in the dustfall was below the national limits, save for two occasions at Site 2. Deposition of sulphur and nitrogen at the inland sites were below the respective critical load values.
\end{abstract}

KEY WORDS: lead, nitrogen deposition, sulphates, sulphur deposition

Dustfall measurement is rarely used in air quality monitoring programmes, although still declared as a standard method in the field. Technical improvements in production facilities and/or monitoring equipment, as well as advances in environmental protection are the reasons why this simple method is rarely used in air quality monitoring programmes. It has, however, been employed recently in ambient air pollution monitoring not only in developing countries (1-3) but also in Australia (4). The same method proved its suitability for indoor dust measurements (5). By definition, dustfall comprises coarse solid and liquid particles, with an aerodynamic diameter $>10 \mu \mathrm{m}$, that are collected via gravitational settling in an open-mouth container for a designated period of time. The method is applicable to area surveys to determine particle fallout nuisance, as well as wet and dry deposition (6). Dustfall is the result of physical processes like abrasion, grinding, or combustion (fly ash and soot). Important sources of dustfall are shipyards and quarries.
First measurements of dustfall in the greater Rijeka area date back to 1975 , to background air quality measurements in the new industrial area (Bakar Bay) with petroleum refinery, an oil fired power plant, and a coke plant, located east of the city. In 1982, dustfall measurements were extended to the city of Rijeka itself, in 1986 to the nearby islands of Krk and Cres, and in 1995 to the mountainous inland area of Gorski Kotar. This study brings dustfall measurements from 1975 to 2008, taken at seven industrial, urban, or remote sites, during which time some industrial facilities were built, their production changed, and some were shut down, which affected the air quality in the area.

\section{MATERIALS AND METHODS}

\section{Location of sampling sites}

The location of sampling sites is given in Figure 1. Sites 1,2 , and 3 represent urban areas with 
considerable industrial emission; sites 4 and 5 are remote sites representative of long-range transport; and Sites 6 and 7 were chosen within an area claimed to have high sulphur and nitrogen depositions due to acid rains.

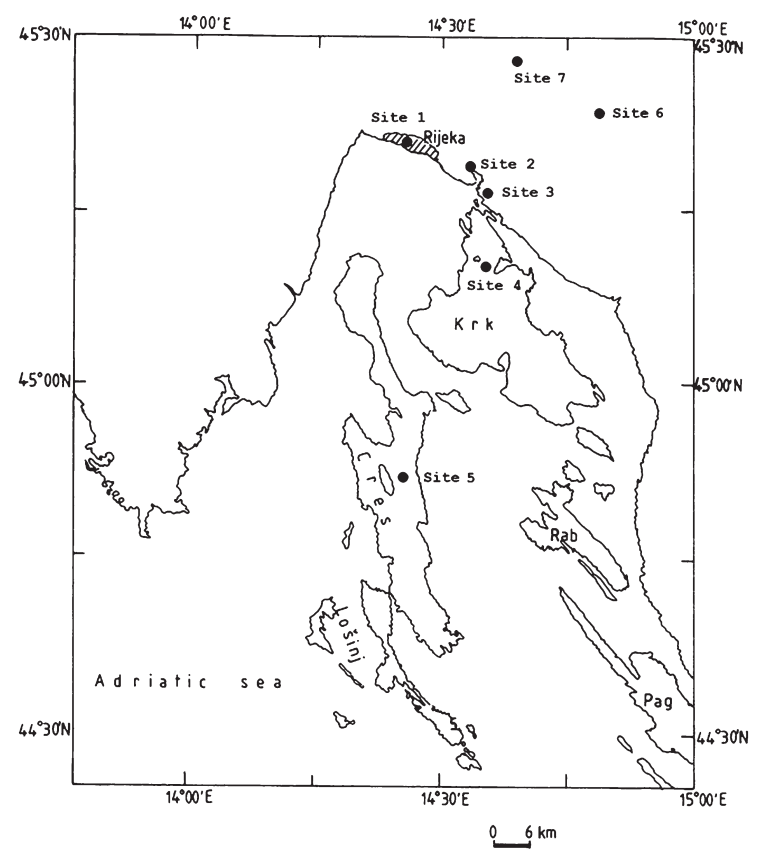

Figure 1 Location of sampling sites

Site 1: Rijeka city centre; (city population ca. 145,000), $20 \mathrm{~m}$ above the sea level (a.s.l.), dividing the harbour from the residential areas;

Site 2: Bakar town centre (population 7,800), $20 \mathrm{~km}$ east of Rijeka, $20 \mathrm{~m}$ a.s.l., a former industrial area (coke plant) with a still active harbour to the east and a petroleum refinery $1.5 \mathrm{~km} S S W$ from the town;

Site 3: town of Kraljevica (population 4,600), 25 $\mathrm{km}$ east of Rijeka, $16 \mathrm{~m}$ a.s.l., located to the east of the Bakar Bay mouth, about $1.5 \mathrm{~km}$ ESE from the petroleum refinery, and $0.5 \mathrm{~km} \mathrm{WNW}$ from the shipyard;

Site 4: Jezero, Island of Krk; an uninhabited remote site, about $25 \mathrm{~km}$ SE of Rijeka, $6 \mathrm{~m}$ a.s.l.

Site 5: Vrana, Island of Cres, an uninhabited remote site, about $100 \mathrm{~km}$ south of Rijeka, $250 \mathrm{~m}$ a.s.l.

Site 6: town of Delnice (population 6,200) in the mountainous inland area of Gorski Kotar, $700 \mathrm{~m}$ a.s.l., about $40 \mathrm{~km}$ east of Rijeka

Site 7: Lividraga; an uninhabited resort in Gorski Kotar, $930 \mathrm{~m}$ a.s.l., about $25 \mathrm{~km}$ NE of Rijeka.

\section{Analytical methods}

We collected dustfall using an apparatus constructed according to German standards. It consisted of a holder and a gauge carrying a polyethylene vessel (Figure 2). Sampling time was (30 \pm 2 ) days. Insoluble matter, soluble matter, and ash were determined gravimetrically (6). Total particulate deposition was calculated as the sum of insoluble and soluble

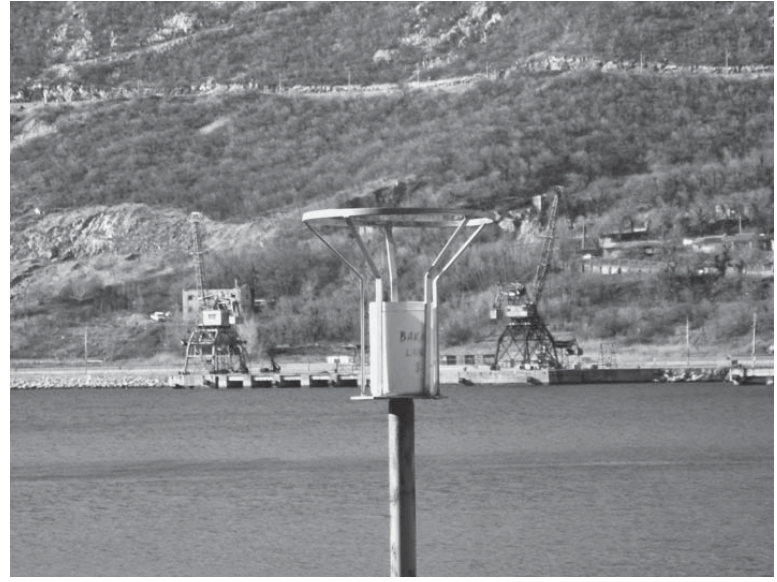

Figure 2 Apparatus for dustfall collection

matter, while combustible matter was obtained as the difference between insoluble matter and ash. Nitrate and ammonium content were determined spectrophotometrically (7), while turbidimetry was used to determine sulphates in the soluble fraction (7) of the dustfall. Lead content was determined using graphite furnace atomic absorption spectrometry of dustfall ash dissolved in $25 \%$ hydrochloric acid, pro analysis grade.

\section{RESULTS AND DISCUSSION}

\section{Dustfall and insolubles}

National legislation on air pollution has undergone a number of changes over the 34 years of dustfall measurements described in this article. Previous legislation on air quality (8) defined two levels of quality standards for dustfall: the recommended (guideline) value $\left(\mathrm{RV}=200 \mathrm{mg} \mathrm{m}^{-2} \mathrm{~d}^{-1}\right)$ and the limit value ( $\left.L V=350 \mathrm{mg} \mathrm{m}^{-2} \mathrm{~d}^{-1}\right)$. According to the 1995 Clean Air Act (9), if the monitoring data were below the recommended value for dustfall, the air was defined as clean or slightly polluted. If the data exceeded the recommended value but were lower than the limit value, the air was classified as moderately polluted. Levels exceeding the limit value were classified as excessive pollution. The new Clean Air Act of 2004 (10) and the new Regulation on limit and tolerable values (11) have merged the two levels of quality standards for dustfall into a single limit value of $350 \mathrm{mg} \mathrm{m}^{-2} \mathrm{~d}^{-1}$. The new Regulation classifies air into two categories: clean or slightly polluted and moderately polluted. For easier comparison, we decided to categorise all dustfall measurements 


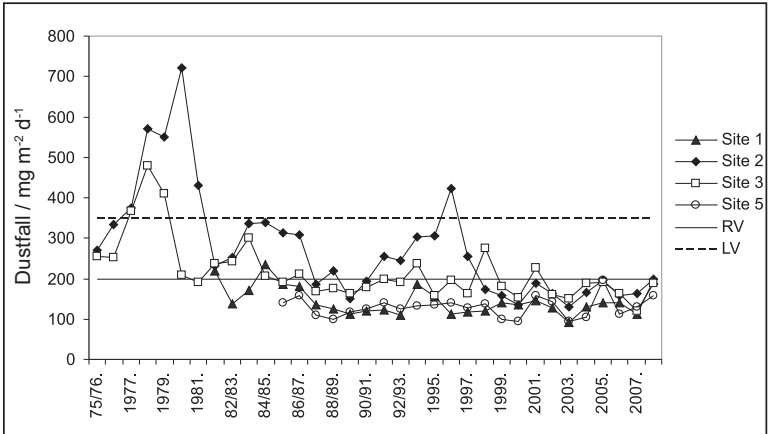

Figure 3 Time trends in total dustfall at selected sites $(R V$ recommended value; $L V$ - limit value)

according to the 1995 Regulation, as most of the monitoring was done before new standards applied.

Time trends in dustfall at selected sites are given in Figure 3. The highest dust levels were recorded at Sites 2 and 3 at the turn of the 1980s, coinciding with the startup of the coke plant at Site 2 (Bakar). The impact of emissions from Bakar on Site 3 (Kraljevica) is reflected in the positive correlation between values obtained at both sites, as follows: dustfall $(\mathrm{r}=0.576$, $\mathrm{P}<0.05)$, ash $(\mathrm{r}=0.516 \mathrm{P}<0.05)$, and sulphates $(\mathrm{r}=0.627$, $\mathrm{P}<0.05)$. For the most of the turn of the 1980 s air was excessively polluted with dustfall $\left(>350 \mathrm{mg} \mathrm{m}^{-2} \mathrm{~d}^{-1}\right)$. By 1981 pollution dropped to moderate at both Sites 2 and 3, due to measures taken to reduce it. These pollution levels continued into the 1990s at Site 2 (Bakar), with the exception of 1996, when dustfall levels provisionally soared as the coke plant was being dismantled after the shutdown at the end of 1994. Since 1998, Site 2 had low dustfall pollution. At Site 3 (Kraljevica), dustfall pollution was low in the mid 1980s, with the exception of 1998 and 2001, when pollution rose to moderate. This was the result of the post-war revival of shipyard activity. Dustfall pollution of Rijeka (Site 1) was moderate in 1982, and peaked in 1984/85.

After the coke plant was shut down and dismantled at Site 2 (Bakar), airborne levels of combustible matter (Figure 4A), as an indicator of coal and/or coke, declined to the levels measured at Site 3 (Kraljevica). However, at the same Site 3, the amount of ash, which is indicative of inorganic substances, increased as a result of increased shipyard activity (Figure 4B).

\section{Lead}

Determination of lead in dustfall started in 1984 in Rijeka, Bakar, and Kraljevica (Sites 1, 2, and 3,
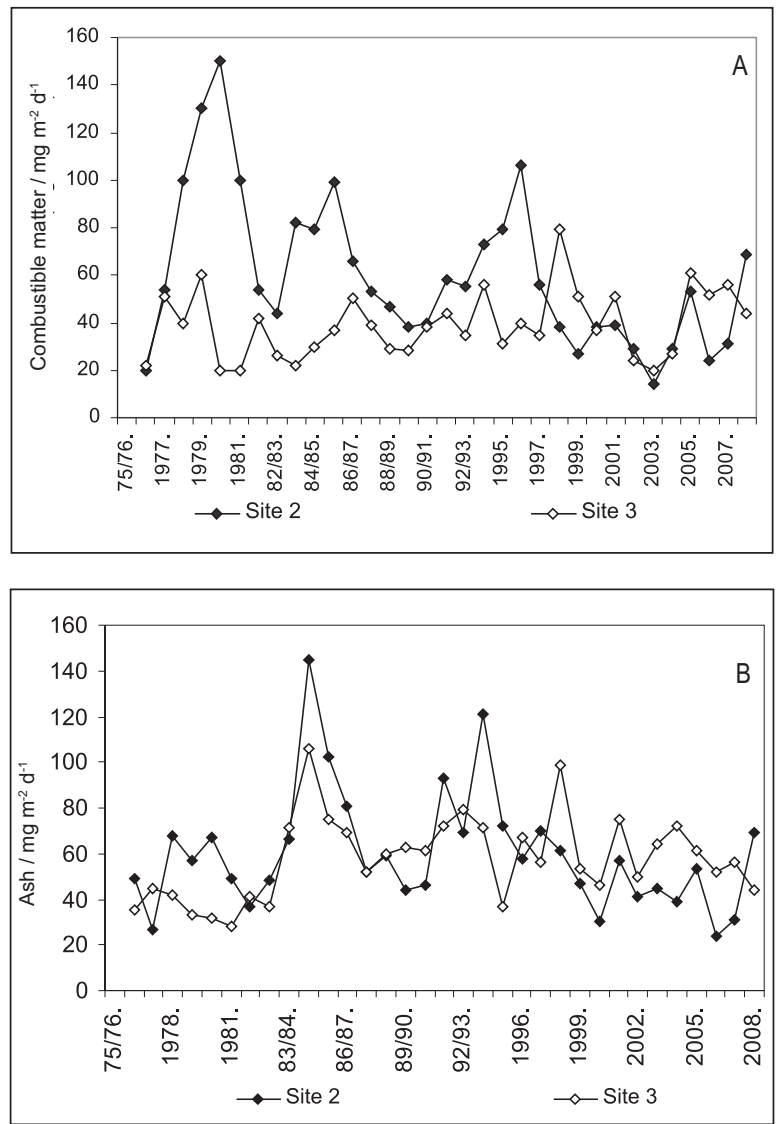

Figure 4 Annual means of: A - combustible matter and $B$ - ash in dust fall

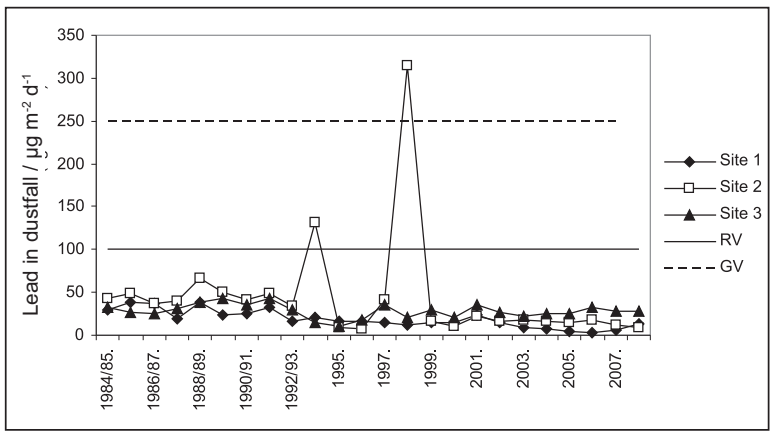

Figure 5 Lead in dustfall ( $R V$-recommended value; $L V$-limit value)

respectively), and since 1996 these analyses had been extended to the islands of Krk and Cres (Sites 4 and 5) and the mountainous hinterland (Site 7). Lead content in dustfall was below the recommended value of $100 \mu \mathrm{g} \mathrm{m}^{-2} \mathrm{~d}^{-1}$ (8) at all sites throughout the studied period, with the exception of Site 2 (Bakar) in 1993/94 when airborne lead pollution was moderate, and in 1998 when it was excessive (Figure 5). The first peak coincided with the last year of the coke-plant 


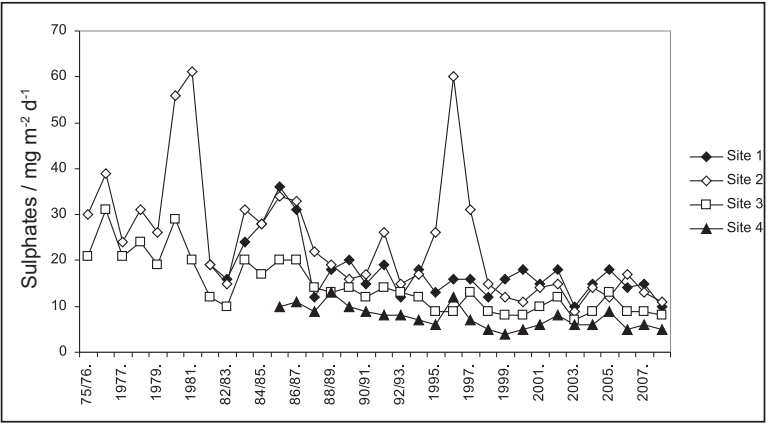

Figure 6 Sulphates in dust fall

production and its shutdown, and the second with the plant's dismantling. The lowest dustfall lead levels of $<10 \mu \mathrm{g} \mathrm{m}^{-2} \mathrm{~d}^{-1}$ were measured at the island Sites 4 and 5 and the mountain Site 7 (Lividraga). While lead in dustfall was decreasing at Sites 1 and 2, it had been increasing at Site 3 (Kraljevica) since the mid-nineties when the shipyard revived.

\section{Sulphates and nitrates}

The levels of sulphates deposited in dustfall ( $\mathrm{mg}$ $\mathrm{m}^{-2} \mathrm{~d}^{-1}$ ) also exhibit a declining trend (Figure 6). The highest levels were measured at Site 2 (Bakar) at the beginning of the coke plant activity (1981-82) and at the time of its shutdown and dismantling (1997). Except for the 1997 high, the trend of sulphates in dustfall at urban Site 1 (Rijeka) correlates with Site 2 (Bakar), evidencing the long lifetime and good mixing of this airborne pollutant in the planetary boundary layer. The lowest sulphate levels in dustfall were measured at the remote island Sites 4 and 5.

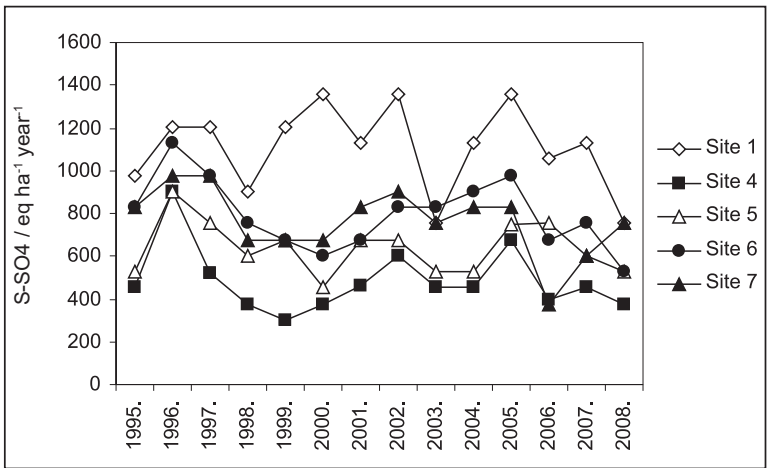

Figure 7 Annual deposition of sulphur as sulphates $\left(\mathrm{S}_{-} \mathrm{SO}_{4}{ }^{2-}\right)$

Throughout the measurement period, daily nitrate levels in dustfall kept within the range of $1 \mathrm{mg} \mathrm{m}^{-2} \mathrm{~d}^{-1}$ to $11 \mathrm{mg} \mathrm{m}^{-2} \mathrm{~d}^{-1}$ (data not shown). The highest levels were measured at Sites 1, 2, and 3 at different time periods.

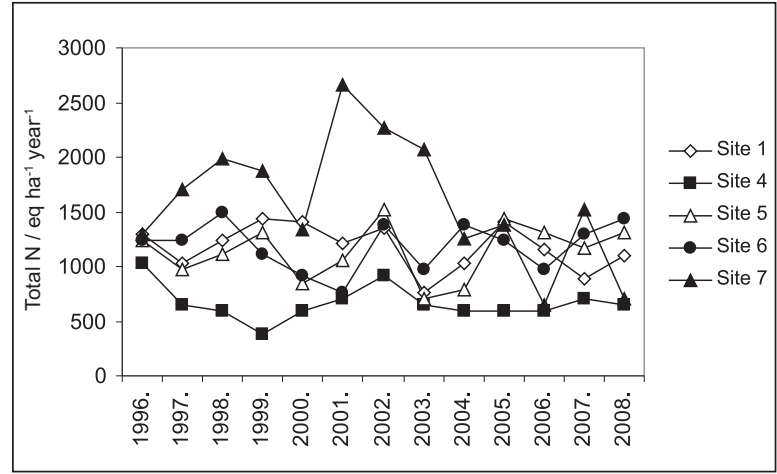

Figure 8 Annual deposition of total nitrogen $\left(\mathrm{N}-\mathrm{NO}_{3}^{-}+\mathrm{N}-\mathrm{NH}_{4}^{+}\right)$

\section{Deposition of sulphur and nitrogen}

Concentrations of sulphate, nitrate, and ammonium ions determined in the soluble part of dustfall were used to estimate the total (wet+dry) deposition of sulphur as sulphate $\left(\mathrm{S}^{-} \mathrm{SO}_{4}{ }^{2-}\right)$ and total nitrogen tot- $\left(\mathrm{N}^{-} \mathrm{NO}_{3}{ }^{-}+\mathrm{N}-\mathrm{NH}_{4}{ }^{+}\right)$. Figures 7 and 8 include estimates for Site 1 (Rijeka) and island Sites 4 and 5 for comparison.

Site 1 shows the highest deposition of sulphur as sulphate $\left(\mathrm{S}_{-} \mathrm{SO}_{4}{ }^{2-}\right)$. This is in agreement with rainwater bulk-sample analyses that showed higher precipitation weighted averages (PWA) of sulphur and nitrogen species at urban Site 1 than at remote Sites 5 and 6. Higher PWA concentrations of sulphates, nitrates, and ammonium at the polluted urban Site 1 were attributed to the local washout of the atmosphere $(12,13)$. The lowest sulphur deposition was recorded at the remote island Sites 4 and 5. Annual S-SO ${ }_{4}^{2-}$ depositions at Site 6 (602 eq ha ${ }^{-1}$ year $^{-1}$ to $1129 \mathrm{eq} \mathrm{ha}^{-1}$ year $\left.^{-1}\right)$ and inland mountain Site 7 (678 eq ha ${ }^{-1}$ year $^{-1}$ to $979 \mathrm{eq} \mathrm{ha}^{-1}$ year $^{-1}$ ) were similar and below the critical load (CL) of sulphur not only for the forest type soil at these sites (Calcic Cambisol and rendzinas; $\mathrm{CL}=3649$ eq ha $^{-1}$ year $\left.{ }^{-1}\right)$, but also for the most susceptible soil type in Gorski Kotar ; CL=1444 eq ha ${ }^{-1}$ year $^{-1}$ ) (14).

The deposition of total nitrogen, tot-N (N-

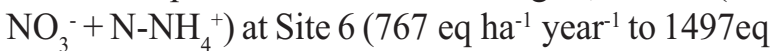
ha $^{-1}$ year $\left.^{-1}\right)$, and Site 7 (1257 eq ha ${ }^{-1}$ year $^{-1}$ to $2657 \mathrm{eq}$ $\mathrm{ha}^{-1}$ year $^{-1}$ ), was also below the $\mathrm{CL}$ values for soil types in these areas $\left(\mathrm{CL}=4603 \mathrm{eq} \mathrm{ha}^{-1}\right.$ year $\left.^{-1}\right)$. For the most susceptible soil type in Gorski Kotar, however, tot-N exceeded the CL (1745 eq ha ${ }^{-1}$ year $\left.{ }^{-1}\right)$ at Site 7 in five of the 14 years of monitoring (14). As precipitation depth varies considerably with orography, it is hard to estimate possible harmful effects of nitrogen deposition outside Sites 6 and 7. There is a possibility 
Table $1 \mathrm{~N}-\mathrm{NH}_{4}^{+} /$tot-N ratio at Site 1 (Rijeka) and inland mountain Site 7 (Lividraga)

\begin{tabular}{|c|c|c|c|c|c|c|}
\hline \multirow[b]{2}{*}{ Year } & \multicolumn{3}{|c|}{ Site 1} & \multicolumn{3}{|c|}{ Site 7} \\
\hline & $\begin{array}{c}\mathrm{N}-\mathrm{NH}_{4}^{+} / \\
\text {eq ha } \text { year }^{-1}\end{array}$ & $\begin{array}{c}\text { Tot-N / } \\
\text { eq } \text { ha }^{-1} \text { year }^{-1}\end{array}$ & $\begin{array}{c}\mathrm{N}-\mathrm{NH}_{4}^{+} / \\
\text {tot-N }\end{array}$ & $\begin{array}{c}\mathrm{N}-\mathrm{NH}_{4}^{+} / \\
\text {eq ha } \text { year }^{-1}\end{array}$ & $\begin{array}{c}\text { Tot-N / } \\
\text { eq ha } \text { hear }^{-1}\end{array}$ & $\begin{array}{c}\mathrm{N}-\mathrm{NH}_{4}^{+} / \\
\text {tot-N }\end{array}$ \\
\hline 1996 & 813 & 1293 & 0.63 & 813 & 1293 & 0.63 \\
\hline 1997 & 610 & 1030 & 0.59 & 1220 & 1700 & 0.72 \\
\hline 1998 & 813 & 1233 & 0.66 & 1627 & 1987 & 0.82 \\
\hline 1999 & 1017 & 1437 & 0.71 & 1627 & 1867 & 0.87 \\
\hline 2000 & 813 & 1413 & 0.58 & 1220 & 1340 & 0.91 \\
\hline 2001 & 610 & 1210 & 0.50 & 2237 & 2657 & 0.84 \\
\hline 2002 & 813 & 1353 & 0.60 & 2034 & 2273 & 0.89 \\
\hline 2003 & 407 & 767 & 0.53 & 1830 & 2070 & 0.88 \\
\hline 2004 & 610 & 1030 & 0.59 & 1017 & 1257 & 0.81 \\
\hline 2005 & 813 & 1413 & 0.58 & 1017 & 1377 & 0.74 \\
\hline 2006 & 610 & 1150 & 0.53 & 407 & 647 & 0.63 \\
\hline 2007 & 407 & 886 & 0.46 & 1220 & 1520 & 0.80 \\
\hline 2008 & 610 & 1093 & 0.56 & 407 & 707 & 0.58 \\
\hline Mean value & 668 & 1177 & 0.58 & 1283 & 1592 & 0.78 \\
\hline
\end{tabular}

of a slight underestimate for these sites because samples could not be collected when the snowfall was high. The dominant component in bulk tot-N deposition was ammonium (15), particularly in the forests, which are the biogenic source of ammonia. The same is true for nitrogen deposition estimated from dustfall measurements (Table 1).

A bit surprisingly, the lowest deposition of tot- $\mathrm{N}$ and $\mathrm{S}_{-} \mathrm{SO}_{4}{ }^{2-}$ was measured at the island Site 4 (Krk) instead of, as expected, Site 5 (Cres), which is farther from the mainland pollution sources. An analysis of air mass back trajectories to and within the Rijeka Bay might clarify this finding, but it does not exclude the impact of local sources. Dry deposition estimates, which are a difference between dustfall and bulk wet deposition, show that sulphur contributed to Site 1 pollution with $70 \%$, and to the inland mountain Site 7 up to $30 \%$. By contrast, dry nitrogen deposition was about $30 \%$ at Site 1 , and up to $45 \%$ at Site 7 . This evidences the biogenic source of gaseous ammonia.

\section{CONCLUSION}

During the whole studied period that comprised extensive industrialisation and pollution in the coastal area, the quantities of dustfall in the urban Site 1 (Rijeka), remote island Sites 4 and 5, and in the mountainous Gorski Kotar (Delnice and Lividraga,
Sites 6 and 7 respectively) were low. Annual means of dustfall exceeded temporarily the recommended and limit values (1979-1994) at industrial Site 2 due to emissions from the coke plant and harbour ore handling. The same applies for Site 3, that initially suffered from emissions from the coke plant, but recently, since the mid-nineties, increased activity in the local shipyard has been the main source of dustfall. This is another evidence that dustfall pollution is limited to the nearby pollution source environment. Deposition of sulphur and total nitrogen at sites 6 and 7 , within the mountainous area, which had been claimed to suffer from acidic deposition, was below the respective critical loads for the soil-vegetation forest types in the areas studied and therefore cannot be responsible for the observed forest decline.

\section{REFERENCES}

1. Wu SP, Tao S, Xu FL, Dawson R, Lan T, Li BG, Chao J. Polycyclic aromatic hydrocarbons in dustfall in Tijanjin, China. Sci Total Environ 2005;345:115-26.

2. Liu LY, Shi PJ, Gao SY, Zou XY, Erdon H, Yan P, Li XY, Ta WQ, Wang JH, Zhang CL. Dustfall in China's western loess plateau as influenced by dust storm and haze events. Atmos Environ 2004;38:1699-703. 
3. Khan FU, Shakila B, Ghauri EG, Ahnmad M. Air pollution in Peshawar (rate of dustfall). Pakist J Sci Ind Res 2002;45:16.

4. Queensland Government, Environmental Protection Agency Queensland Health. Mount Cotton Quarries Dust Investigation March/April 2008 [displayed 2 December 2009]. Available at https://www.epa.qld.gov.au/register/ p02453aa.pdf.

5. Würtz H, Sigsgaard T, Valbjørn O, Doekes G, Meyer HW. The dustfall collector: a simple passive tool for long-term collection of airborne dust; a project under the Danish Mould in Buildings program (DAMIB). Indoor Air 2005;15(Suppl 9):33-40.

6. Lodge Jr JP, editor. Methods of Air sampling and Analysis. $3^{\text {rd }}$ ed. Boca Raton (FL); CRC Press; 1988. p. 440-3.

7. Greenberg A. Standard Methods for the Examination of Water and Wastewater. $16^{\text {th }}$ ed. Washington (DC): American Public Health Association; 1985.

8. Uredba o preporučenim i graničnim vrijednostima kakvoće zraka [Regulation on guideline and limit values, in Croatian] Narodne novine 101/1996.

9. Odluka o proglašenju Zakona o zaštiti zraka [Clean air act, in Croatian]. Narodne novine 48/1995.
10. Zakon o zaštiti zraka [Clean air act, in Croatian]. Narodne novine 178/2004.

11. Uredba o graničnim vrijednostima onečišćujućih tvari u zraku [Regulation on limit values of air pollutants, in Croatian]. Narodne novine 133/2005.

12. Alebic-Juretic A. Precipitation chemistry within Kvarner Bay Area (Croatia), 1984-1991. Water Air Soil Pollut 1994;78:343-57.

13. Alebić-Juretić $\mathrm{A}$, Šjojat $\mathrm{V}$. Chemical composition of rainwater collected at two sampling sites in the City of Rijeka. Arh Hig Rada Toksikol 1988;49:245-50.

14. Jelavić V, Martinović M, Vranković A, Šatalić S.Vrijednosti kritičnih opterećenja šumskog ekosustava sumporom i dušikom na području zapadne Hrvatske - prvi rezultati [Critical loads for sulphur and nitrogen in forest ecosystems in Western Croatia, preliminary results, in Croatian]. In: Maceljski M. editor. Zbornik radova "Prilagodba poljoprivrede i šumarstva klimi i njenim promjenama". Zagreb: HAZU, 1988. p. 279-87.

15. Alebic-Juretic A, Micovic M. Bulk deposition of nitrogen within Kvarner bay area (Croatia), 1984-2003. In: Zhu Z, Minami K, Xing G editors. Third International Nitrogen Conference; $12-16$ Oct 2004. Nanjing, China. Contributed papers. Science press, USA 2005. p. 644-9. 


\section{Sažetak}

UKUPNA TALOŽNA TVAR NA PODRUČJU PRIMORSKO-GORANSKE ŽUPANIJE U RAZDOBLJU 1975.-2008.

Ispitivanja ukupne taložne tvari u Primorsko-goranskoj županiji započela su 1975. godine na području Bakarskog zaljeva. Mjerenja su se 1982. god proširila na grad Rijeku, 1986. na otoke Krk i Cres, a 1995. i na područje Gorskog kotara. U radu su prikazani rezultati mjerenja ukupne taložne tvari u razdoblju 1975.-2008. na sedam odabranih postaja: u gradu Rijeci, dvije na području Bakarskog zaljeva (Bakar i Kraljevica), dvije na otocima (Krk i Cres) te dvije u Gorskom kotaru (Delnice i Lividraga). Analizirano je kretanje prosječnih godišnjih vrijednosti ukupno istaloženih tvari te u njima prisutnih količina sagorivog pepela, sulfata, nitrata, amonija i olova. Na području grada Rijeke, otoka Krka i Cresa te Gorskog kotara količina ukupne taložne tvari je niska. Količine ukupne taložne tvari povremeno su prelazile preporučenu graničnu vrijednost u Bakru (1979.-1994.), zbog emisija iz koksare i iz luke za rasuti teret te u Kraljevici, gdje se osamdesetih godina osjećao utjecaj koksare u Bakru, a od sredine devedesetih pojačani rad u brodogradilištu. Količine olova u taložnoj tvari su niske na svim postajama, osim povremenih skokova u Bakru, kada su prijeđene preporučene vrijednosti. Količine istaloženog sumpora i dušika na području Gorskog kotara ispod su odgovarajućih vrijednosti kritičnog opterećenja za ispitivana područja.

KLJUČNE RIJEČI: olovo, sulfati, taloženje dušika, taloženje sumpora

\section{CORRESPONDING AUTHOR:}

Ana Alebić-Juretić, PhD

Teaching Institute of Public Health

Krešimirova 52a, HR-51000 Rijeka, Croatia

E-mail:ana.alebic@zzjzpgz.hr 